\title{
MENJALIN UKHUWAH MENUMBUHKAN GHIRAH KEPADA GURU YAYASAN NABEEHA ULYA DESA BLABAK KECAMATAN KANDAT KABUPATEN KEDIRI
}

\author{
Ema Nurzainul Hakimah \\ Program Studi Manajemen Universitas Nusantara PGRI Kediri \\ emahakimah@unpkediri.ac.id
}

\begin{abstract}
Teachers "digugu and imitated" wherever they are are personal figures with noble character and it must be realized by the actors as the main figures in the school environment. This main role is often not realized by teachers either as professionals or as part of an organization. Based on these preliminary observations, a training with the theme "Establishing Ukhuwah Fostering Ghirah" to the teachers of the Nabeeha Ulya Foundation, with the aim of fostering empathy and loyalty to the institutions where they serve both the MI Al Ikhlash work unit and Khodijah PAUD. The stages carried out in this activity began from the initial survey of two institutions under the Nabeeha Ulya Foundation, identification of various problems in the organization, training with resource persons, simulations, assistance and evaluation. The results of this training have an impact on increasing understanding of individual behavior in organizations and openness to convey understanding of the vision and mission of each institution. Keywords: teacher, training, organizational behavior

ABSTRAK

Guru "digugu dan ditiru" di mana pun berada adalah sosok pribadi yang berkarakter mulia dan itu harus disadari oleh para pelakunya sebagai figur utama di lingkungan sekolah. Peran utama ini sering kali kurang disadari oleh guru baik sebagai profesional maupun bagian dari sebuah organisasi. Berdasarkan observasi awal tersebut maka dilaksanakanlah pelatihan dengan tema "Menjalin Ukhuwah Menumbuhkan Ghirah" kepada para guru-guru Yayasan Nabeeha Ulya, dengan tujuan untuk menumbuhkan empati dan loyalitas kepada lembaga tempat mereka mengabdi baik di unit kerja MI Al Ikhlash maupun di PAUD Khodijah. Tahapan yang dilakukan dalam kegiatan ini dimulai dari survei awal terhadap dua lembaga yang dinaungi Yayasan Nabeeha Ulya, identifikasi berbagai masalah dalam organisasi, pelatihan dengan nara sumber, simulasi, pendampingan dan evaluasi. Hasil pelatihan ini berdampak pada peningkatan pemahaman terhadap perilaku individu dalam organisasi dan keterbukaan menyampaikan pemahaman terhadap visi misi lembaga masing-masing.
\end{abstract}

Kata kunci: guru, pelatihan, perilaku organisasi 


\section{PENDAHULUAN}

Jenjang pendidikan dasar yang ada di Indonesia meliputi PAUD, TK/RA, SD/ MI, SMP/ MTs, SMA/ SMK/ MA, yang mana berada di bawah naungan dan tanggung jawab Kementerian Pendidikan dan Kebudayaan Republik Indonesia (Kemendikbud) dan Kementerian Keagamaan Republik Indonesia (Kemenag). Dalam proses meningkatkan kualitas pendidikan di setiap jenjangnya yang menjadi instrumen pendobrak utama adalah guru, hal ini dikarenakan guru sebagai pendidik di sekolah. Dalam melaksanakan berbagai tugas dan tanggungjawabnya sebagai seorang guru akan selalu bertemu dan berinteraksi dengan teman sejawat, peserta didik, wali murid dan warga sekolah lainnya. Seorang guru memiliki tanggung jawab untuk mendidik, mengajar, membimbing peserta didik, menjadi jembatan antara sekolah dengan orang tua siswa dalam penyenggaraan program sekolah, melaksanakan tugas tambahan sebagai struktural di sekolah, dan sekaligus sebagai masyarakat yang bertanggungjawab kemajuan generasi bangsa Indonesia di masa yang akan datang.

Fungsi pendidikan di jenjang pendidikan dasar adalah menumbuhkan potensi peserta didik melalui bimbingan guru yang profesional dan bekerja secara optimal. Terkadang guru merasa malas, tidak bersemangat, jenuh atau bosan dalam menjalankan tugasnya sebagai guru. Guru pun beranggapan bahwa tugasnya hanya mentransfer pengetahuan yang dimilikinya dengan target tersampaikan topik-topik yang tertulis dalam kurikulum. Dalam praktiknya masih sering dijumpai tugas guru dalam menyampaikan ilmu sangat monoton dan tidak memberi inspirasi kepada siswa untuk berkreasi dan melatih siswa untuk mandiri sehingga pelajarannya kurang menantang siswa untuk berpikir akibatnya siswa tidak bersemangat dalam belajar. Hal ini akan sangat berpengaruh negatif terhadap perkembangan siswa, bila terjadi pada guru jenjang PAUD, TK/ RA dan SD/ MI.

Dengan demikian, guru yang profesional pasti memiliki kinerja tugas yang tinggi diharapkan dapat melaksanakan tugas dalam meningkatkan potensi peserta didiknya dan sekaligus menggerakkan sekolah mencapai visi dan tujuannya. Dalam melaksanakan tugas pengajaran, seorang guru harus dapat memanfaatkan waktu belajar di kelas sesuai dengan rencana pembelajaran yang dibuat. Sehingga guru dapat 
memberikan konstribusi dalam belajar sebagai hasil tingkah laku dalam keterampilan, kemampuan dan pengetahuan yang ingin dicapai bersama warga sekolah terutama pada peserta didik. Tugas tambahan sebagai struktural organisasi sekolah, sama pentingnya untuk dilaksanakan dengan penuh tanggung jawab. Keselarasan pelaksanaan tugas dan fungsi ini menjadi komitmen seorang guru di sekolah masing-masing, dan sekaligus komitmen sebagai guru tetap yayasan.

Guru yang bekerja di lembaga pendidikan swasta, diangkat dan ditugaskan untuk melaksanakan tugas-tugas pengajaran dan struktural sekolah berdasarkan keputusan yayasan yang menaungi pendidikan tersebut. Guru yang mengajar disemua jenjang pendidikan dasar dengan status guru tetap yayasan memiliki tugas dan fungsi yang sama dengan guru berstatus Pegawai Negeri Sipil (PNS). Namun demikian, gaji atau penghasilan guru tetap yayasan dan guru PNS tidak dapat disamakan tingkat kesejahteraannya secara ekonomi. Faktor rendahnya tingkat penghasilan guru tetap yayasan sering kali menjadi pemicu rendahnya profesionalisme dan komitmen. Hal inilah yang menjadikan alasan diperlukannya pembinaan yang bersifat berkesinambungan oleh penyelenggara pendidikan yaitu yayasan.

Usaha pembinaan dan pengembangan mutu guru yayasan wajib dilakukan dalam rangka memotivasi semangat juang para guru yaitu hanya mengharap Ridhlo Allah SWT dan bekerja hanya Lillahita'ala (bekerja ikhlash karena Allah SWT.). Yayasan dituntut untuk terus merancang, melaksanakan, dan mengevaluasi berbagai macam kegiatan pembinaan kepada guru yang berkerja dibawah naungannya. Setiap yayasan melakukan berbagai strategi dan program kerja untuk dapat mengelola dan mengoptimalkan setiap aset yang dimiliki termasuk guru (sumber daya manusia) sebagai aset utama berhasilnya visi dan tujuan yayasan dan sekaligus yang utama adalah visi misi sekolah itu sendiri. Kekuatan sumber daya manusia dalam yayasan yaitu guru, secara langsung akan berdampak positif terhadap peningkatan prestasi sekolah-sekolah yang dinaungi oleh yayasan tersebut baik dalam hal akademik maupun non akademik.

Hakikat mengembangkan lembaga dan memenangkan persaingan ini harus dimaknai mencapai keunggulan kompetitif melalui perbaikan kualitas sekolah/ madrasah berdasarkan standar nasional pendidikan. Kedepannya persaingan itu menjadi dorongan dan kebiasaan penyelenggara pendidikan untuk terus memperbaiki 
kualitasnya, sehingga pendidikan di Indonesia semakin berkualitas, berkarakter dan terjangkau bagi semua lapisan masyarakat.

Yayasan akan bekerjasama dengan kepala sekolah dalam melaksanakan program-program kerjanya. Tugas fungsi pokok kepala sekolah/madrasah mengacu pada Permendiknas Nomor 19 Tahun 2007 tentang standart pengelolaan sekolah, meliputi (1) perencanaan program, (2) pelaksanaan rencana kerja, (3) pengawasan dan evaluasi, (4) kepemimpinan sekolah, (5) sistem informasi sekolah, selanjutnya dapat didiagramkan sebagai berikut:

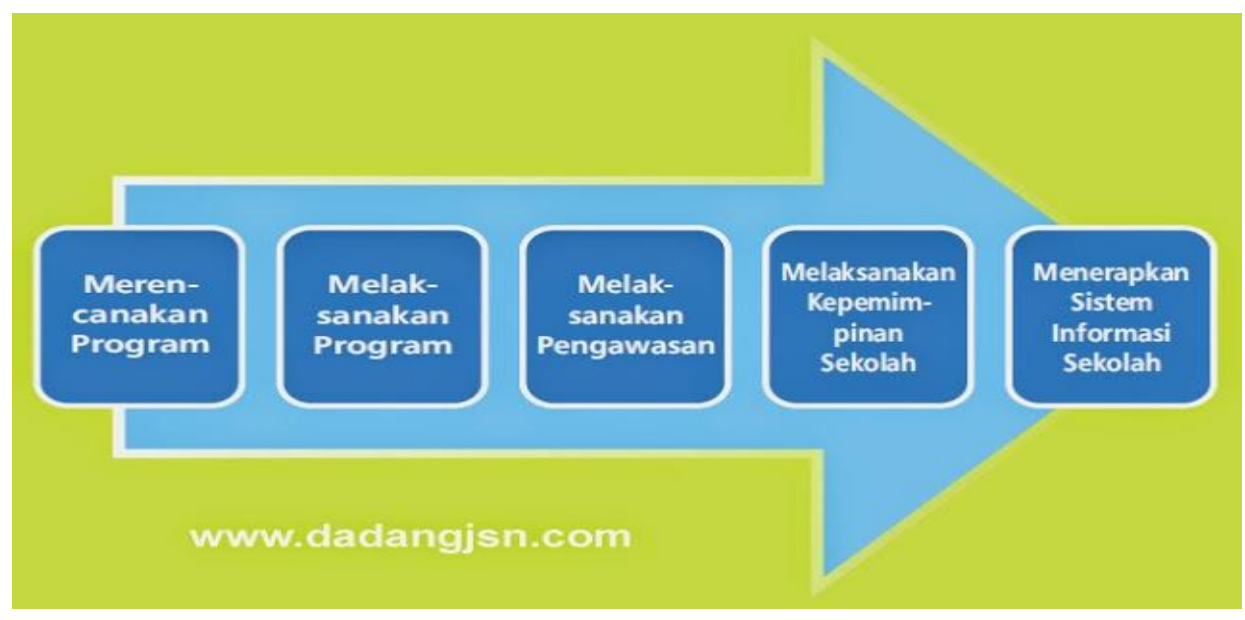

Diagaram tersebut memberikan arahan proses manajerial yang harus dilakukan oleh kepala sekolah sebagai pelaksana pendidikan di sekolah. Setiap tahapan tersebut memerlukan kemampuan dan komitmen yang tinggi dalam melaksanakannya, dari proses inilah akan tercipta berbagai peningkatan kualitas sekolah. Peningkatan mutu pendidikan, pelayanan sekolah, kualitas pembelajaran, prestasi-prestasi guru dan siswa akan membanjiri sekolah, ketika seorang kepala sekolah mampu mengelola dengan baik aset utama sekolah yaitu guru.

Yayasan Nabeeha Ulya yang berada di desa Blabak kecamatan Kandat kabupaten Kediri, menaungi dua lembaga pendidikan yaitu Madrasah Ibtidaiyah (MI) dan Pendidikan Anak Usia Dini (PAUD) Khodijah. Jumlah sumber daya manusia yang dimiliki sebanyak 22 orang terdiri dari 18 orang guru, 1 tenaga administrasi dan 3 orang tenaga kebersihan. Sebagai penyelenggara pendidikan formal dan non formal, yayasan hanya memiliki sebidang tanah wakaf produktif seluas $1740 \mathrm{~m}^{2}$, sehingga tidak 
mencukupi untuk membantu operasional sekolah setiap bulannya. Berdasarkan informasi yang diperoleh dari ketua Yayasan Nabeeha Ulya, motif dan landasan utama pendirian yayasan dan lembaga pendidikan ini adalah Jihad fii Sabilillah (berjuang di jalan Allah). Sehubungan dengan hal tersebut, berjalannya waktu terjadi masalah terhadap rendahnya komitmen guru terhadap pelaksanaan tugas dan fungsi guru sebagai pendidik sekaligus pelaksana tugas struktural di sekolah masing-masing. Rendahnya tingkat kehadiran guru dalam rapat, hasil rapat yang disepakati bersama tetapi dilaksanakan, seringnya terjadi miss communication antara guru-siswa-wali murid, dan tidak maksimalnya kegiatan yang diprogramkan oleh sekolah.

Total siswa pada tahun pelajaran 2018/2019 dari kedua lembaga pendidikan sebanyak 180 siswa, yang terdiri dari 115 siswa MI dan 65 siswa PAUD. Potensi besar ini harus dapat dikelola dengan maksimal. Kepercayaan masyarakat menitipkan putraputrinya menimba ilmu di sekolah-sekolah yang dinaungi Yayasan Nabeeha Ulya harus tetap dipertahankan dan ditingkatkan. Untuk itu yayasan memprogramkan kegiatan pembinaan dan peningkatan mutu guru secara periodik dan berkesinambungan.

Guru sebagai aset utama sekolah harus menyadari perannya dengan baik dilandasi semangat Jihat Fii Sabilillah, sehingga visi misi yayasan dan sekaligus visi misi sekolah yang dinaungi dapat segera terwujud dan keunggulan bersaing dapat diciptakan. Terciptanya keunggulan bersaing bagi sebuah sekolah merupakan hal penting untuk keberlangsungan dan kemakmuran sekolah tersebut di masa yang akan datang.

\section{METODE PELAKSANAAN}

Kegiatan pengabdian masyarakat ini terwujud dari koordinasi dan kerjasama Program Studi Manjemen Universitas Nusantara PGRI Kediri bersama Yayasan Nabeeha Ulya yang beralamat di desa Blabak kecamatan Kandat kabupaten Kediri. Sasaran utama kali ini adalah para kepala sekolah dan guru di lingkup Yayasan Nabeeha Ulya. Kegiatan yang dilakukan meliputi:

1. Pelatihan bidang Sumber Daya Manusia dengan judul "Menjalin Ukhuwah Menumbuhkan Ghirah", dilaksanakan pada tanggal 9 - 10 Juli 2019. Tim dari program studi manajemen mempunyai tugas untuk memberikan pengetahuan dan 
wawasan tentang manajemen pemasaran jasa, perilaku organisasi, manajemen sumber daya manusia dan nilai-nilai pengabdian "Lillah-Billah"

2. Simulasi manejemen konflik individu dalam organisasi dari sudut jihad $f i$ sabilillah, mengingat organisasi ini adalah lembaga pendidikan yang berdasar ibadah, dengan dihubungkan dengan pendalaman ID - Ego - dan Super Ego menjadi penekanannya.

3. Pendampingan dan evaluasi praktik secara organisasional dalam 2 bulan.

Pemaparan materi tentang manajemen pemasaran jasa oleh Ema Nurzainul Hakimah, M.M., mendudukkan secara praktis bahwa sekolah merupakan salah satu bentuk bisnis yang bergerak dibidang jasa. Bahwa secara strategi pemasarannya menggunakan 7 hal dalam marketing mix jasa, yaitu product, price, pleace, promotion, process, physical avidence, dan people (Kotler: 2010), dan bagaimana menciptakan kepuasan konsumen melalui excellent services sehingga konsumen menjadi loyal (Lovelock: 2005). Hal-hal utama yang harus dilakukan dalam mewujudkan pelayanan prima di sekolah meliputi:

1. Pertama, terapkan senyum dalam lingkungan sekolah.

2. Kedua, timbulkan sifat optimis, yaitu berani berfikir positif dan maju.

3. Ketiga, buatlah mereka terkesan. Seperti tagline atau slogan sebuah iklan parfum ternama yang berbunyi "kesan pertama begitu menggoda, selanjutnya terserah anda."

4. Keempat, bersikap antusias. Bergairah atau semangat, begitu kata KBBI (Kamus Besar Bahasa Indonesia). Guru harus punya seribu satu cara dalam mengajar.

5. Kelima, punya loyalitas. Mengikuti apa yang di tetapkan oleh manajemen merupakan satu kerjasama yang baik. Tanpa adanya loyalitas, maka visi dan misi sekolah tidak akan tercapai dengan baik. (Ardhiaditya: 2018)

Materi kedua yang disampaikan tentang nilai-nilai pengabdian "Lillah-Billah", disampaikan oleh Ibu Diah Ayu Septi Fauji, M.M. Pada kesempatan ini narasumber mengajak diskusi dan bersama-sama mendefinisikan makna ukhuwah, ghirah dan sejauh mana nilai-nilai tersebut dimaknai dan dipahami implikasinya terhadap sebuah organisasi. 


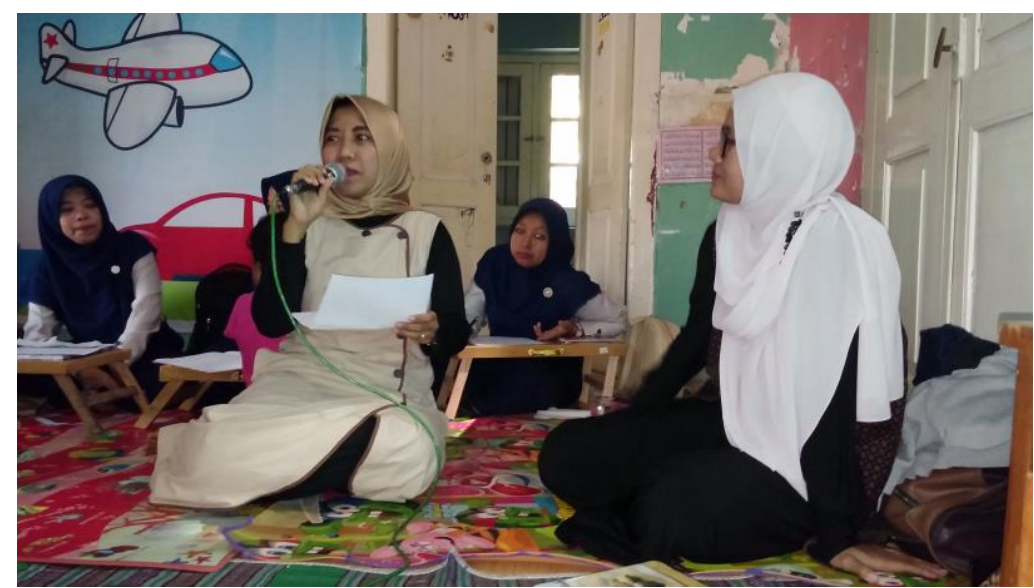

Gambar 1. Peserta memaparkan makna ukhuwah dan ghirah bersama pemateri

Narasumber yang ketiga yaitu Ibu Restin Meilina, M.M., menyampaikan keilmuan bidang sumber daya manusia dan perilaku organisasi.

\title{
ORGANISASI
}
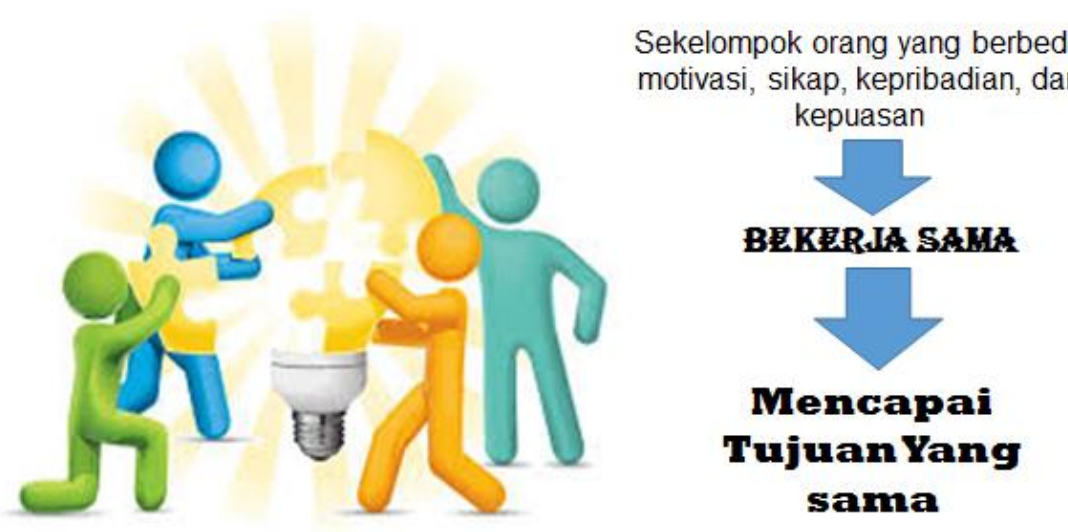

Gambar 2. Slide materi tentang dasar organisasi

Teori Kepribadian Sigmund Freud

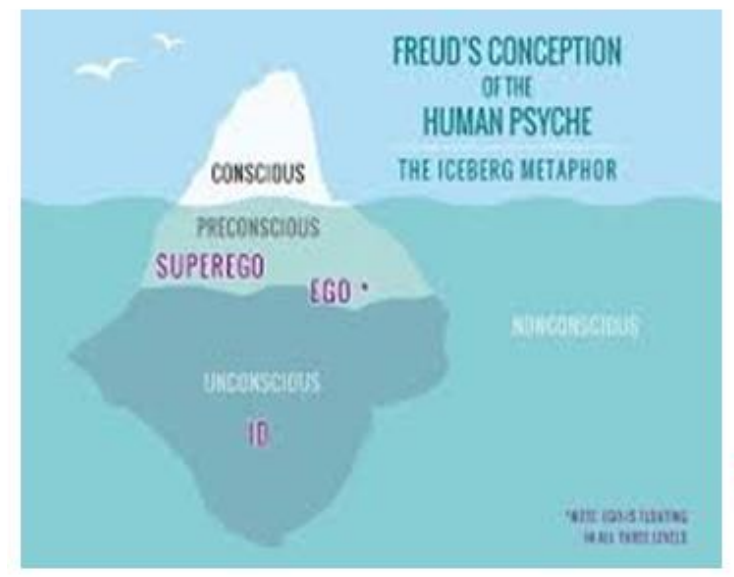

\author{
Setiap tindakan \\ manusia, pasti \\ melalui \\ pertarungan \\ antara \\ ID vs SUPER EGO
}

(C) 2019 Jurnal Abdi Masyarakat Universitas Kadiri | 7 


\section{Gambar 3. Slide materi tentang kebijakan akan lahir dari teori Sigmund Freud}

Penjelasan pemateri ketiga sangat menekankan bagaimana seseorang harus bersikap prefesional dan mendukung sebuah organisasi dan bagaimana dia harus menyeimbangkan dirinya sendiri dengan konflik yang terjadi. Al Qur'an surat Al Qoshash ayat 26 adalah petunjuk dasar dari teori the right man on the right place serta teori tentang perilaku organisasi.

\section{HASIL DAN PEMBAHASAN}

Keberhasilan sesi penyampaian materi dari narasumber pada kegiatan ini dapat dilihat dari beberpa indikator, meliputi:

1. $100 \%$ peserta yang di undang hadir dalam pelatihan.

2. Terlaksananya seluruh kegiatan pelatihan, dengan antusiasme yang tinggi. Peserta banyak yang bertanya saat sesi tanya jawab, tidak ada peserta yang meninggalkan tempat sebelum acara selesai, peserta tidak ada yang absen dan mengikuti semua rangkaian kegiatan pelatihan.

3. Peserta dan lembaga sama-sama mendapatkan informasi terkait perspektif peserta tentang kebersamaan, komitmen melaksanakan tugas dan fungsi sebagai guru melalui angket terbuka, dan pemahaman peserta terhadap visi misi sekolah masingmasing yang masih rendah.

4. Adanya pernyataan kepuasaan dari guru-guru yang mengikuti pelatihan.

5. Adanya MOU antara Program Studi Manajemen Universitas Nusantara PGRI Kediri dengan Yayasan Nabeeha Ulya.

Tahap kedua dari pelatihan ini adalah simulasi bagaimana memaknai dan menciptakan ukhuwah dan ghirah. Ekspresi dan gesture pada peserta langsung dapat dimaknai oleh sesama peserta maupun oleh narasumber. Fenomena ini lagsung menjadi titik poin dari narasumber untuk kegiatan selanjutnya. Kebersamaan dan loyalitas yang masih sangat perlu untuk didampingi dan diarahkan sehingga kedepan masih diperlukan program-program peningkatan mutu guru baik secara akademik maupun spiritual building. 


\section{Gambar 4. Ekspresi dan gesture dari peserta}

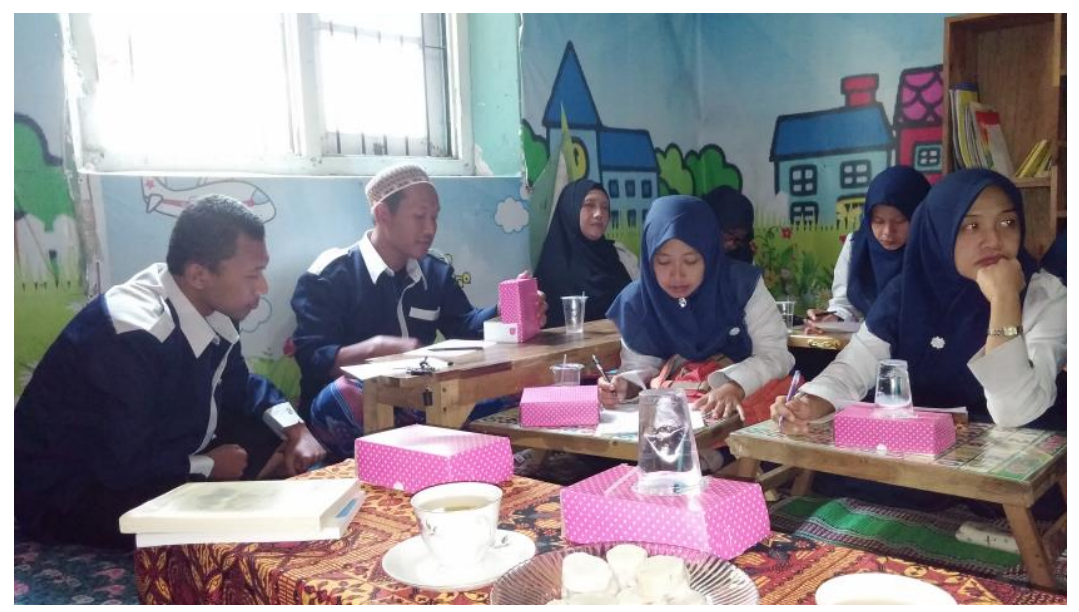

Tahap terakhir kegiatan pengabdian untuk Kepala Sekolah dan Guru Yayasan Nabeeha Ulya adalah pendampingan dan evaluasi. Adapun beberapa hal yang menjadi catatan antara lain:

1. Perlu sekali untuk terus melakukan pengawasan dalam rangka meningkatkan kesadaran, motivasi dan mampu merubah mindset peserta menjadi guru profesional.

Sebelumnya mereka hanya berpikir dan bertindak asal mengajar, menyampaikan materi, dan sekedar mengikuti acara pembinaan atau rapat.

2. Selama masa pendampingan terjadi perbaikan soft skill dan hard skill mitra dalam bidang ilmu pengetahuan Manajemen Sumber Daya Manusia (MSDM), dan yang lebih penting dari itu adalah berubahnya mindset mereka tentang keingingan untuk menjadi guru yang berkualitas, professional dan hanya mengharap ridhlo Allah SWT.

\section{KESIMPULAN}

Guru sebagai roh pendidikan di sekolah secara terprogram memerlukan suntikan keilmuan, motivasi baik bersifat spiritual maupun materi, pendampingan dan pengawasan yang konsisten guna mewujudkan profesionalisme dan tercapainya tujuan lembaga pendidikan dalam hal ini adalah visi misi Yayasan Pendidikan yang 
menaunginya. Pengabdiam kepada masyarakat wujud tridharma dosen dan kolaborasi dengan masyarakat ini mampu menjadi solusi bagi lembaga-lembaga untuk memperbaiki kinerja organisasinya. Dengan demikian sinergi positif ini perlu untuk direncanakan dan diprogramkan sehingga terintegrasi dengan baik.

\section{DAFTAR PUSTAKA}

Lovelock, C. Wright, L. (2005).ManajemenPemasaranJasa. Jakarta : PT. IndeksKelompokGramedia.

Parasuraman, Leonard L. Berry, and Valerie A. Zeithml.(1988). "SERVQUAL : A Multiple-Item Scale for Measuring Customer Perceptions of Service Quality".

Permendiknas Nomor 19 Tahun 2007 tentang standart pengelolaan sekolah

https://www.kompasiana.com/ardhiaditya/5a9eb447f133446b4310c5a2/bagaimanameningkatkan-pelayanan-sekolah. 